\title{
Perkembangan Spasial Kota-Kota Kecil Di Jawa Tengah
}

\author{
Nanda Adi Prawatya ${ }^{1}$ \\ Kementerian Pekerjaan Umum \\ DKI Jakarta, Indonesia
}

\begin{abstract}
Abstrak: Tingkat urbanisasi di Provinsi Jawa Tengah meningkat dengan melihat adanya perubahan yang terjadi pada luas penggunaan lahan pertanian yang semakin menurun khususnya di kota kecil . Dalam kurun waktu 10 tahun penggunaan lahan terbangun di Jawa Tengah meningkat sebesar 70,1\%. Selain itu dalam kurun waktu 10 tahun jaringan jalan meningkat sebesar $0,43 \%$. Hal ini dikarenakan daya tampung urbanisasi dan pergerakan aktivitas di kota besar sudah semakin meningkat dan tidak dapat menampung pada satu titik saja, sehingga diperlukan daerah lain dengan tujuan untuk pemerataan. Hal ini menimbulkan beberapa pertanyaan yaitu apa saja faktor pembentuk ruang perkotaan dan bagaimana perkembangan spasial kota-kota kecil di Jawa Tengah. Tujuan penelitian ini adalah untuk mengetahui tipologi kota-kota kecil di Jawa Tengah berdasarkan aspek struktur ruang, tata guna lahan dan infrastruktur. Kota-kota kecil yang berstruktur konsentris perkembangan lahan terbangunnya terbilang lambat dikarenakan hanya terdapat pusat kegiatan yang bersifat tunggal serta potensi daerah tersebut merupakan daerah rural urban yang pusat kegiatannya hanya dari sektor pertanian. Kota kecil yang berstruktur multiple nuclei perkembangan lahan terbangunnya cukup berkembang antara tingkat sedang sampai tingkat tinggi. Hal ini dikarenakan adanya beberapa pusat kegiatan di dalam kota kecil tersebut mengakibatkan tingginya perkembangan lahan terbangun. Berdasarkan pola tipologi spasial kota-kota kecil dijelaskan bahwa kota-kota kecil di pinggiran kota besar seperti Kota Surakarta, Yogyakarta, Semarang, Tegal, Magelang, Salatiga dan Pekalongan perkembangan kotanya masih memiliki ketergantungan terhadap kota induk. Jadi, perkembangan kota tidak hanya dipengaruhi oleh urbanisasi tetapi ada faktor lain yaitu seperti comparative advantages bersifat alamiah (topografi, SDA, historis) maupun buatan (jaringan infrastruktur, fasilitas sosial).
\end{abstract}

Kata kunci: aspek spasial, kota kecil, perkembangan kota

\begin{abstract}
The level of urbanization in Central Java province is increased by looking at the changes occurred in the vast agricultural land use that has declined, especially in a small town. In the past 10 years, built-up land use in Central Java has increased by 70.1\%. In addition, also in the past 10 years the road network has increased by $0.43 \%$. This happened because the capacity of urbanization and activities movement in a large city is increasing and can not accommodate at one point, so that other areas are required for equalization purpose. This raises several questions, such as what the determining factors of urban space are and how the spatial development of small towns in Central Java is. The purpose of this study was to determine the typology of small towns in Central Java based on aspects of the space structure, land use and infrastructure. Small towns are concentric structured with slow land development because there is only a single activity center. The potential of the area is a rural urban area with its center activity only from the agricultural sector. Multiple nuclei structured
\end{abstract}

\footnotetext{
${ }^{1}$ Korespondensi Penulis: Kementerian Pekerjaan Umum, DKI Jakarta, Indonesia Email: nandaadiprawatya@yahoo.com
} 
small towns are quite developed between moderate to high level. This is due to the existence of several centers within the small towns that resulted in high development of built-up land. Based on spatial typology pattern of small towns, it can be explained that the small towns located on the outskirts of major cities such as Surakarta, Yogyakarta, Semarang, Tegal, Magelang, Salatiga, and Pekalongan, have a dependency to those main city. Thus, city development is not only influenced by urbanization, but also other factors such nature comparative advantages (topography, natural resource, historical) and human made physic (infrastructure network, social facilities).

Keywords: city development, small towns, spatial aspects

\section{Pengantar}

Fenomena perkembangan kota dewasa ini mulai sering terjadi di Pulau Jawa, khususnya di Jawa Tengah. Provinsi Jawa Tengah memiliki beberapa pusat kegiatan yang berskala nasional, wilayah dan lokal. Berdasarkan data dari BPS Pusat, Provinsi Jawa Tengah merupakan salah satu provinsi yang padat penduduk dengan kepadatan mencapai $994,9 / \mathrm{km} 2$ pada tahun 2010. Hal ini dapat menimbulkan potensi suatu daerah untuk berkembang. Kondisi tersebut berpotensi menimbulkan pusat-pusat pertumbuhan aktivitas baru yang dapat mempengaruhi perubahan tata guna lahan. Wilayah yang berpotensi memunculkan aktivitas-aktivitas baru adalah kota-kota kecil yang secara administratif berada di dekat kota besar maupun daerah yang memiliki keunggulan kondisi fisik yang berpotensi untuk berkembang sebagai fungsi kawasan heterogen. Menurut Handayani (2010) mengindikasikan bahwa perubahan tata guna lahan non pertanian meningkat dari tahun 1994 sampai 2006. Perpaduan antara rendahnya tingkat lahan terbangun, tingginya pergeseran mata pencarian penduduk dari pertanian ke sektor industri/jasa dan relatif rendahnya pertumbuhan kontribusi sektor non pertanian di PDRB mengindikasikan munculnya daerah-daerah di Jawa Tengah yang berwajah kota kecil.

Fenomena perkembangan kawasan perkotaan tersebut terlihat jelas pada pola keruangan perkembangan penduduk perkotaan, terutama di Jawa memperlihatkan kecenderungan perkembangan koridor perkotaan yang menghubungkan antara kota-kota besar seperti koridor Serang-Jakarta-Kerawang, koridor Jakarta-Bandung, koridor CirebonSemarang, koridor Semarang-Yogyakarta, serta koridor Surabaya-Malang, dimana pembentukan koridor-koridor tersebut sering diwarnai oleh semakin kaburnya perbedaan antara wilayah perkotaan dengan wilayah pedesaan (Firman, 1992:213). Munculnya fenomena tersebut tidak terlepas dari keberadaan jalur transportasi yang menghubungkan antar kota-kota tersebut, sehingga akan terbentuk semacam koridor perkotaan antara kotakota besar. Selain itu, terjadinya perkembangan kawasan perkotaan di sekitar kota besar maupun di sepanjang koridor antar kota besar juga ditandai dengan adanya proses restrukturisasi internal pada kota-kota tersebut, baik secara sosial-ekonomi maupun secara fisik. Secara fisik proses restrukturisasi ditandai oleh adanya perubahan guna lahan, baik di kota inti maupun di kawasan pinggiran. Kawasan pusat kota mengalami perubahan penggunaan lahan sangat intensif dari kawasan permukiman menjadi komersil, sedangkan di kawasan pinggiran kota terjadi alih fungsi (konversi) lahan pertanian yang subur menjadi kawasan terbangun yaitu industri dan permukiman.

Pesatnya perkembangan daerah perkotaan di sepanjang koridor SurakartaYogyakarta tidak terlepas dari adanya interaksi yang terjadi antara kedua kota tersebut, hal ini karena interaksi antar kota/ wilayah merupakan faktor ekternal yang berpengaruh serta berperan penting terhadap perkembangan suatu kota. Tingkat pertumbuhan dan perkembangan suatu kota terlihat dari seberapa kuat interaksi antar kota/ wilayah di sekitarnya, seperti pergerakan penduduk berupa perjalanan atau migrasi, aliran investasi 
baik berupa aliran aset atau SDM, penyebaran inovasi, aliran informasi dan komoditas yang didorong oleh kemajuan dalam bidang teknologi transportasi, informasi dan produksi. Penelitian pendukung yang pernah dilakukan sebelumnya mengenai penggunaan lahan akibat fenomena urbanisasi adalah perkembangan Kota Ungaran yang dikategorikan dalam zona urban fringe. Hal ini didasarkan penggunaan lahannya yang mencapai lebih dari $60 \%$ total lahan yang ada. Perkembangan Kota Ungaran paling menonjol yang dapat dilihat adalah perubahan tata guna lahan di sepanjang jalan Semarang-Solo. Tata guna lahan didominasi oleh lahan terbangun seperti perdagangan, permukiman dan indusri. Hal ini dipengaruhi oleh gaya hidup masyarakat yang mempengaruhi perkembangan fisik Kota Ungaran. Faktor kondisi fisik yang berpengaruh terhadap gaya hidup adalah dari segi kemudahan akses dalam menjangkau sarana prasarana perkotaan. Masyarakat yang memiliki kemudahan akses dalam menjangkau sarana prasarana perkotaan umumnya berada di kawasan sekitar jaur utama kota (Anawati, 2001).

Secara umum dari informasi di lapangan dalam beberapa tahun terakhir bahwa terdapat beberapa daerah di Jawa Tengah yang mengalami pertumbuhan lahan terbangun yang didominasi oleh fungsi kawasan yang bersifat komersil skala kota maupun regional akibat adanya pengaruh dari urbanisasi. Berdasarkan kondisi di atas, maka perlu dilakukan penelitian mengenai perkembangan spasial kota-kota kecil di Jawa Tengah.

\section{Kajian Teori}

Kota merupakan suatu ruang/wadah manusia dalam melakukan kegiatan dan aktivitas untuk keberlangsungan hidup. Perkembangan kota merupakan proses bertambahnya luas area kota yang dipengaruhi oleh faktor-faktor dari kota itu sendiri. Perkembangan suatu kota dapat dilihat dengan makin meluasnya daerah kota dalam hal ini adalah luas lahan terbangun (non pertanian) mulai meningkat sedangkan luas lahan tidak terbangun (lahan pertanian) semakin berkurang. Variabel penelitian dilakukan berdasarkan kajian literatur yang telah dibahas sebelumnya. Dengan terpilihnya variabel ini akan menjadikan penelitian lebih terarahkan dalam menentukan objek mana yang akan diteliti.

Tabel 1. Sintesis Variabel Penelitian

\begin{tabular}{|c|c|c|c|}
\hline Teori & Penjelasan & Sumber & Manfaat \\
\hline \multicolumn{4}{|c|}{ PERKEMBANGAN SPASIAL KOTA } \\
\hline $\begin{array}{l}\text { Struktur } \\
\text { Ruang } \\
\text { Perkotaan }\end{array}$ & $\begin{array}{l}\text { Pertumbuhan maupun perkembangan yang } \\
\text { terjadi pada suatu kota akan sangat } \\
\text { mempengaruhi kinerja dari pusat kota. } \\
\text { Semakin luas suatu kota, maka akan semakin } \\
\text { menambah "beban" yang ditanggung oleh } \\
\text { pusat kota }\end{array}$ & $\begin{array}{l}\text { - Hadi Sabari } \\
\text { Yunus, } 2002\end{array}$ & $\begin{array}{l}\text { Untuk mengetahui } \\
\text { struktur ruang perkotaan } \\
\text { dari konsentris, sektoral } \\
\text { dan banyak pusat }\end{array}$ \\
\hline $\begin{array}{l}\text { Ruang(Tata } \\
\text { Guna Lahan) }\end{array}$ & $\begin{array}{l}\text { Ada dua tata guna lahan, yaitu: } \\
\text { - Lahan terbangun } \\
\text { - Lahan tak terbangun }\end{array}$ & $\begin{array}{l}\text { - Edward J. } \\
\text { Kaiser, David R } \\
\text { dan Chapin, } \\
1993\end{array}$ & $\begin{array}{l}\text { Untuk mengetahui } \\
\text { persentase lahan } \\
\text { tebangun dalam kurun } \\
\text { waktu } 10 \text { tahun }\end{array}$ \\
\hline
\end{tabular}

Lanjutan Tabel 1.

\begin{tabular}{c|l|c|c}
\hline Teori & \multicolumn{1}{|c|}{ Penjelasan } & Sumber & Manfaat \\
\hline Infrastruktur & Jaringan jalan menurut fungsinya, yaitu: & $\bullet$ UU no 22 tahun & Untuk mengetahui \\
\hline
\end{tabular}




\begin{tabular}{|c|c|c|c|}
\hline jaringan jalan & $\begin{array}{l}\text { - Jalan arteri (jalan nasional, jalan provinsi) } \\
\text { - Jalan kolektor (jalan provinsi, jalan } \\
\text { kabupaten) } \\
\text { - Jalan lokal (jalan kabupaten, jalan kota) } \\
\text { - Jalan lingkungan (jalan desa) }\end{array}$ & $\begin{array}{l}2009 \text { tentang } \\
\text { lalu lintas dan } \\
\text { angkutan jalan }\end{array}$ & $\begin{array}{l}\text { persentase jaringan jalan } \\
\text { dalam kurun waktu } 10 \\
\text { tahun }\end{array}$ \\
\hline Kesimpulan & \multicolumn{3}{|c|}{$\begin{array}{l}\text { Berdasarkan variabel - variabel yang diperoleh dari literatur di atas, maka dapat disimpulkan } \\
\text { variabel dalam penelitian "Perkembangan Spasial Kota-Kota Kecil di Jawa Tengah" antara } \\
\text { lain: } \\
\text { - Struktur ruang perkotaan (pusat kegiatan \& jalur transportasi) } \\
\text { - } \text { konsentris } \\
\text { - sektoral } \\
\text { - banyak pusat } \\
\text { - Tata guna lahan } \\
\text { - terbangun } \\
\text { - Jaringan jalan } \\
\text { - Kerapatan jalan }\end{array}$} \\
\hline
\end{tabular}

\section{Metodologi}

Dalam melakukan penelitian perkembangan spasial di kota-kota kecil Jawa Tengah, perlu diketahui variabel terkait dengan pengembangan wilayah dan pengaruh perubahan struktur perkotaan tersebut. Dengan hipotesis bahwa adanya fenomena urbanisasi di kota besar yang sudah meluas sehingga mengakibatkan pergeseran perkembangan bergeser ke kotakota kecil di sekitar kota besar tersebut.

Tabel 2. Kerangka Desain Penelitian

\begin{tabular}{|c|c|c|c|}
\hline \multicolumn{4}{|c|}{$\begin{array}{l}\text { Tujuan: Mengetahui perkembangan spasial di kota-kota kecil Jawa Tengah dalam kurun } \\
\text { waktu } 10 \text { tahun terakhir }\end{array}$} \\
\hline & $\begin{array}{l}\text { Sasaran } 1 \\
\end{array}$ & \begin{tabular}{|c|} 
Sasaran 2 \\
\end{tabular} & \begin{tabular}{|c|} 
Sasaran 3 \\
\end{tabular} \\
\hline Sasaran & $\begin{array}{l}\text { Identifikasi struktur ruang } \\
\text { perkotaan Jawa Tengah }\end{array}$ & $\begin{array}{l}\text { Identifikasi } \\
\text { perkembangan lahan } \\
\text { terbangun dalam kurun } \\
\text { waktu } 10 \text { tahun }\end{array}$ & $\begin{array}{l}\text { Identifikasi perkembangan } \\
\text { infrastruktur jaringan jalan } \\
\text { dalam kurun waktu } 10 \text { tahun }\end{array}$ \\
\hline Tujuan & $\begin{array}{l}\text { Mengetahui struktur ruang } \\
\text { perkotaan Jawa Tengah }\end{array}$ & $\begin{array}{l}\text { Mengetahui } \\
\text { perkembangan lahan } \\
\text { terbangun th.1999-2009 }\end{array}$ & $\begin{array}{l}\text { Mengetahui perkembangan } \\
\text { infrastruktur jaringan jalan } \\
\text { th.1999-2009 }\end{array}$ \\
\hline Variabel & $\begin{array}{l}\text { - Pusat kegiatan } \\
\text { - Jalur transportasi }\end{array}$ & $\begin{array}{l}\text { - Tata guna lahan } \\
\text { terbangun }\end{array}$ & - Jaringan jalan \\
\hline $\begin{array}{l}\text { Teknik } \\
\text { Analisis }\end{array}$ & $\begin{array}{l}\text { Desktriptif kuantitatf dan } \\
\text { SIG }\end{array}$ & $\begin{array}{l}\text { deskriptif kuantitatif, } \\
\text { komparatif, analisis SIG }\end{array}$ & $\begin{array}{l}\text { deskriptif kuantitatif, } \\
\text { komparatif, analisis SIG }\end{array}$ \\
\hline $\begin{array}{l}\text { Jenis } \\
\text { Data }\end{array}$ & data sekunder (instansi) & data sekunder (instansi) & data sekunder (instansi) \\
\hline
\end{tabular}

\section{Obyek Penelitian}

Penelitian perkembangan spasial kota-kota kecil Jawa Tengah ini merupakan penelitian yang bersifat kuantitatif. Hal ini dikarenakan obyek penelitian yang diteliti terlalu luas dan membutuhkan waktu dan biaya yang cukup banyak sehingga penelitian ini cukup mengandalkan data sekunder. Obyek penelitian ini adalah kota-kota kecil yang berjumlah 50 kota yang tersebar di Jawa Tengah. Kota-kota kecil tersebut berstatus sebagai ibu kota kecamatan di masing-masing kabupaten. Kota-kota kecil tersebut memiliki jumlah 
penduduk yang berkisar antara 25.000-50.000 jiwa. Hal ini dikarenakan daerah tersebut merupakan daerah yang berada dalam proses transisi dari desa ke kota.

\section{Data Penelitian}

Kebutuhan data adalah data yang berkaitan dengan variabel penelitian yang akan diteliti sesuai dengan tujuan penelitian yang dapat mempermudah data yang diperlukan. Tabel kebutuhan data menjelaskan semua hal tentang data tersebut, dimulai dari sasaran, variabel data, tujuan, bentuk data, jenis data, sumber data dan tahun keluarnya data tersebut.

Tabel 3. Kebutuhan Data

\begin{tabular}{|c|c|c|c|c|c|c|c|}
\hline No & Sasaran & $\begin{array}{c}\text { Variabel } \\
\text { Data }\end{array}$ & Tujuan & Bentuk Data & $\begin{array}{l}\text { Jenis } \\
\text { Data }\end{array}$ & $\begin{array}{c}\text { Sumber } \\
\text { Data }\end{array}$ & Tahun \\
\hline 1 & $\begin{array}{l}\text { Identifikasi } \\
\text { struktur ruang } \\
\text { perkotaan } \\
\text { Jawa Tengah }\end{array}$ & $\begin{array}{l}\text { - Pusat } \\
\text { kegiatan } \\
\text { - Jalur } \\
\text { transportasi }\end{array}$ & $\begin{array}{l}\text { Mengetahui } \\
\text { struktur } \\
\text { perkotaan } \\
\text { Jawa Tengah }\end{array}$ & - Foto udara & $\begin{array}{l}\text { Sekunder } \\
\text { (Internet) }\end{array}$ & $\begin{array}{c}\text { Google } \\
\text { Earth }\end{array}$ & 2012 \\
\hline 2 & $\begin{array}{l}\text { Identifikasi } \\
\text { perkembangan } \\
\text { lahan } \\
\text { terbangun } \\
\text { dalam kurun } \\
\text { waktu } 10 \\
\text { tahun }\end{array}$ & $\begin{array}{l}\text { - Lahan } \\
\text { terbangun }\end{array}$ & $\begin{array}{l}\text { Mengetahui } \\
\text { perkembangan } \\
\text { lahan } \\
\text { terbangun } \\
\text { th.1999-2009 }\end{array}$ & $\begin{array}{l}\text { - Peta } \\
\text { - Dokumen } \\
\text { perencanaan } \\
\text { - Data dalam } \\
\text { bentuk tabel } \\
\text { dan diagram }\end{array}$ & $\begin{array}{l}\text { Sekunder } \\
\text { (Instansi) }\end{array}$ & $\begin{array}{c}\text { Podes } \\
\text { Jawa } \\
\text { Tengah, } \\
\text { RTRW } \\
\text { Jawa } \\
\text { Tengah }\end{array}$ & $\begin{array}{l}1999- \\
2009\end{array}$ \\
\hline 3 & $\begin{array}{l}\text { Identifikasi } \\
\text { perkembangan } \\
\text { infrastruktur } \\
\text { jaringan jalan } \\
\text { dalam kurun } \\
\text { waktu } 10 \\
\text { tahun }\end{array}$ & $\begin{array}{l}\text { - Kerapatan } \\
\text { jalan }\end{array}$ & $\begin{array}{l}\text { Mengetahui } \\
\text { perkembangan } \\
\text { infrastruktur } \\
\text { jaringan jalan } \\
\text { th.1999-2009 }\end{array}$ & $\begin{array}{l}\text { - } \text { Peta } \\
\text { - Dokumen } \\
\text { perencanaan } \\
\text { - Data dalam } \\
\text { bentuk tabel } \\
\text { dan diagram }\end{array}$ & $\begin{array}{l}\text { Sekunder } \\
\text { (Instansi) }\end{array}$ & $\begin{array}{l}\text { Peta Rupa } \\
\text { Bumi } \\
\text { Indonesia }\end{array}$ & $\begin{array}{l}2000- \\
2009\end{array}$ \\
\hline
\end{tabular}

\section{Kerangka Analisis}

Tahap pertama adalah menentukan obyek penelitian yang akan diteliti. Untuk dapat menetukan obyek penelitian perlu melakukan proses pengklasifikasian. Peta jumlah penduduk per desa di-overlay dengan peta status desa yang berstatus kota. Tahap selanjutnya adalah melakukan pengelompokan kota-kota tersebut menjadi sebuah perkotaan dengan melihat interaksi kota tersebut dengan daerah di sekitarnya. Setelah terbentuk menjadi perkotaan, maka mulai melakukan pengklasifikasian kota bedasarkan jumlah penduduk yaitu kota metropolitan (1-5 juta penduduk), kota besar (500.000-1 juta penduduk), kota sedang (100.000-500.000 penduduk) dan kota kecil ( $<100.000$ penduduk).

Tahap selanjutnya adalah mengklasifikasikan kembali terhadap kota kecil untuk menentukan obyek penelitian. Klasifikasi yang dilakukan pada kota kecil dibagi menjadi 4 bagian yaitu kota kecil berpenduduk 75.000 sampai 100.000 , kota kecil berpenduduk 50.000 sampai 75.000, kota kecil berpenduduk 25.000-50.000 dan kota kecil berpenduduk kurang dari 25.000. Tahap kedua adalah melakukan analisis data penelitian yaitu analisis struktur ruang perkotaan, analisis perkembangan tata guna lahan terbangun tahun 1999 sampai 2009, dan analisis perkembangan jaringan jalan tahun 1999 sampai 2009. Ketiga analisis tersebut di-overlay dengan obyek penelitian yang sudah ditentukan yaitu kota kecil dengan jumlah penduduk 25.000-50.000 jiwa. Hasil dari analisis struktur ruang perkotaan 


\section{Perkembangan Spasial Kota-Kota Kecil di Jawa Tengah}

adalah struktur ruang kota-kota kecil seperti konsentris, sektoral dan banyak pusat. Hasil dari analisis perkembangan tata guna lahan terbangun tahun 1999 sampai 2009 adalah persentase tingkat perkembangan lahan terbangun. Dan hasil dari analisis perkembangan jaringan jalan tahun 1999 sampai 2009 adalah persentase tingkat kepadatan jalan.

Tahap terakhir adalah melakukan pengelompokan terhadap hasil dari ketiga analisis tersebut. Berdasarkan hasil pengelompokan nantinya diharapkan dapat diketahui bagaimana pola perkembangan spasial kota-kota kecil yang ada di Jawa Tengah.

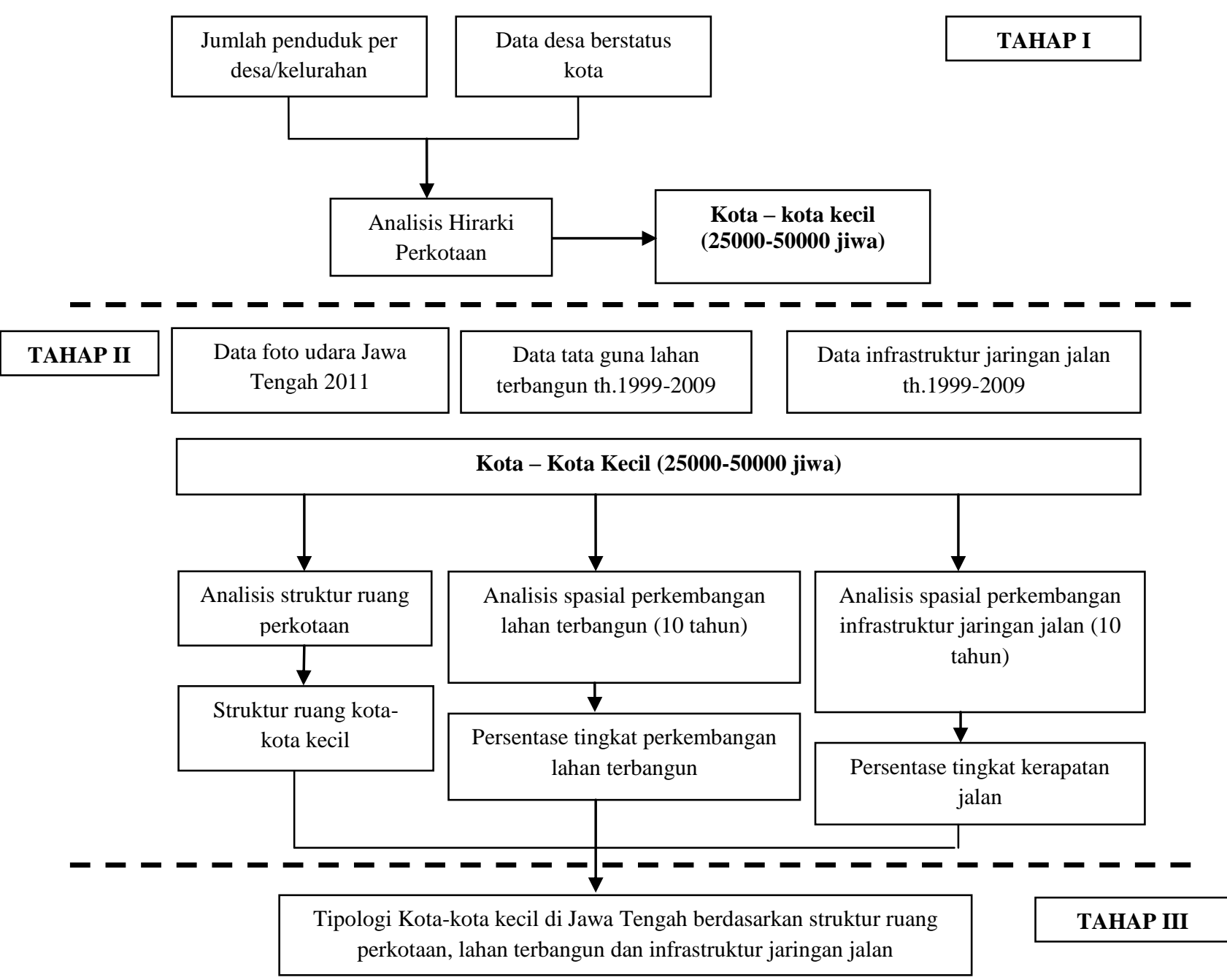

Gambar 1. Kerangka Analisis Penelitian

\section{Hasil Analisis dan Temuan Penelitian}

\section{Analisis Struktur Ruang Kota-Kota Kecil Jawa Tengah (25.000-50.000 Jiwa)}

Kota-kota kecil yang berstruktur ruang kota konsentris berjumlah 12 kota. Kota-kota tersebut beberapa ada yang termasuk dalam klasifikasi rural urban. Hal ini dikarenakan beberapa kota-kota kecil tersebut berkembang secara alami dan berada jauh atau tidak berbatasan langsung dengan kota besar. Sehingga perkembangan kota-kota kecil tersebut 
dapat dikatakan lambat karena tidak ada pengaruh yang besar dari daerah di sekitarnya dan kegiatannya masih bersifat agropolis. Kota-kota kecil tersebut seperti Boja (Kendal), Gemolong (Sragen), Gombong (Kebumen), Jatibarang (Brebes), Kayen (Pati), Kutoarjo (Purworejo), Lasem (Rembang), Margasari (Tegal), Margoyoso (Pati), Moga (Pemalang), Parakan (Temanggung), Randudongkal (Pemalang), Sambi (Boyolali), Sidareja (Cilacap), Sragi (Pekalongan), Tayu (Pati), Wangon (Banyumas), Wedarijaksa (Pati) dan Weru (Sukoharjo). Lokasi kota-kota kecil ini tersebar di lokasi yang berbeda-beda.

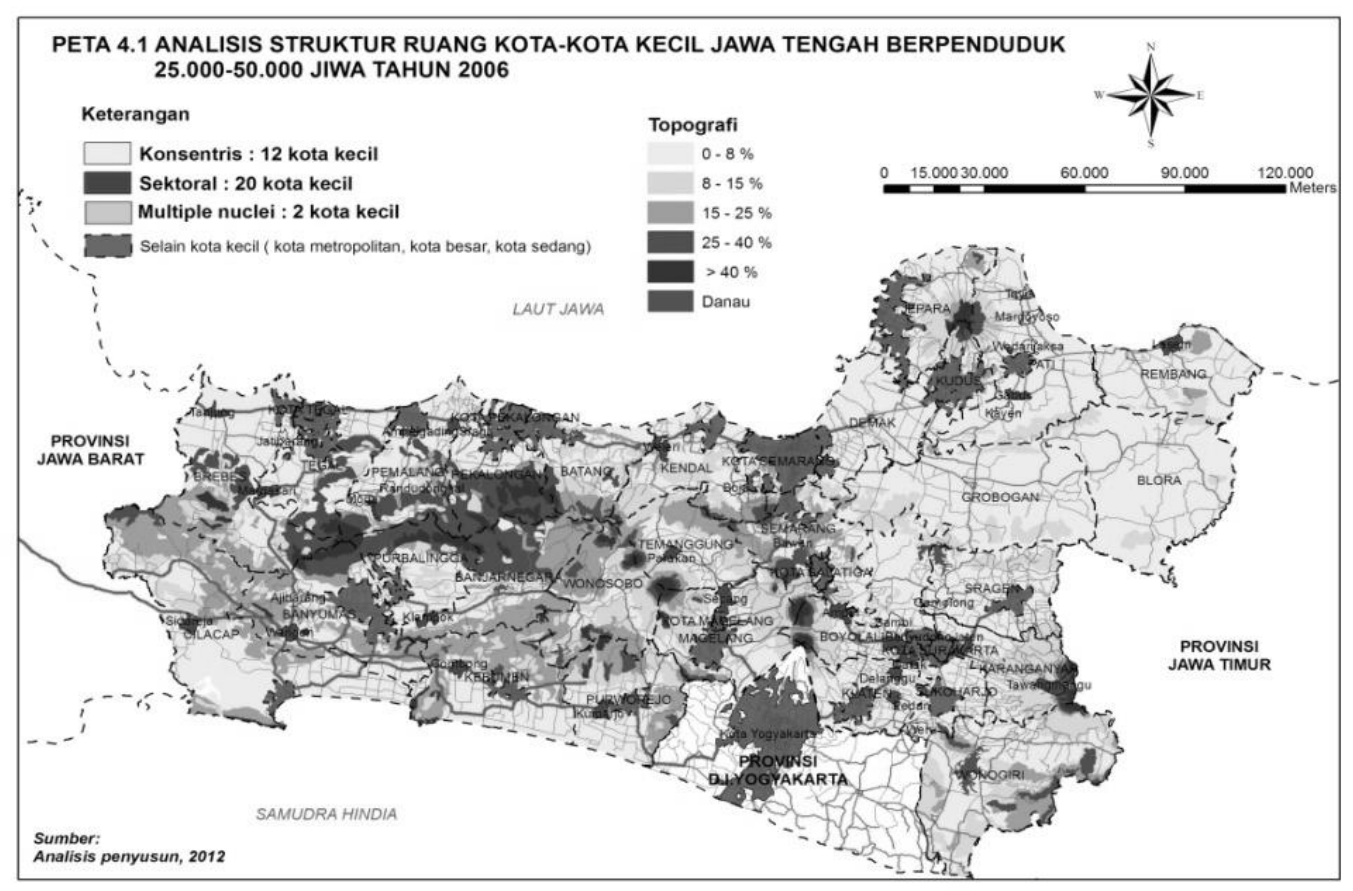

\section{Gambar 2. Peta Analisis Struktur Ruang Kota-Kota Kecil Jawa Tengah (25.000-50.000 jiwa)}

Hasil analisis yang diperoleh adalah unit perkotaan tergolong pada tipe grid kawasan. Pola jaringan jalan utama yaitu berupa jalur utama memiliki bentuk linier dan terpadu dengan sistem jalan lingkungan yang berpola grid. Dilihat dari tingkatan hirarkinya maka pemanfaatan ruang untuk aktivitas perdagangan dan jasa di sekitar jalan utama menempati hirarki tertinggi. Maka dapat disimpulkan bahwa pola struktur ruang konsentris terpadu dengan linier. Jika dilihat melalui pola perkembangannya maka dari awal wilayah studi tumbuh secara horisontal, namun khusus di sekitar jalan utama pertumbuhan kota tumbuh secara vertikal. Hal itu dipengaruhi oleh kondisi kepadatan bangunan dan harga lahan dibanding dengan daerah lain. Kondisi ini sama dengan pengertian struktur konsentris dari Burgess (1925) yaitu rute-rute transportasi dari segala penjuru memusat ke zona ini sehingga zona ini merupakan zona dengan derajat aksesibilitas tinggi.

\section{Analisis Lahan Terbangun Kota-Kota Kecil Jawa Tengah (25.000-50.000 Jiwa)}

Berdasarkan analisis yang pertama yaitu analisis struktur ruang dapat dilihat bagaimana pengaruh struktur terhadap perkembangan lahan terbangun. Tabel di bawah menjelaskan bahwa mayoritas kota-kota kecil yang berstruktur ruang konsentris mengalami perkembangan lahan terbangun yang rendah yaitu sebanyak 8 kota. Hal tersebut sebanding dengan kota-kota kecil yang berstruktur sektoral yang mayoritas memiliki tingkat 


\section{Perkembangan Spasial Kota-Kota Kecil di Jawa Tengah}

perkembangan lahan terbangun yang rendah. Kondisi tersebut berbanding terbalik dengan kota-kota yang berstuktur ruang multiple nuclei. Kota kecil yang berstruktur multiple nuclei perkembangan lahan terbangunnya cukup berkembang antara tingkat sedang sampai tingkat tinggi. Hal ini dikarenakan adanya beberapa pusat kegiatan di dalam kota kecil tersebut mengakibatkan tingginya perkembangan lahan terbangun. Sementara itu untuk kota-kota kecil yang berstruktur konsentris perkembangan lahan terbangunnya terbilang lambat dikarenakan hanya terdapat pusat kegiatan yang bersifat tunggal serta potensi daerah tersebut merupakan daerah rural urban yang pusat kegiatannya hanya dari sektor pertanian.

Tabel 4. Perkembangan Lahan Terbangun Kota-Kota Kecil (25.000-50.000 jiwa) Jawa Tengah Menurut Struktur Ruang

\begin{tabular}{|c|c|c|c|}
\hline $\begin{array}{l}\text { Struktur } \\
\text { Ruang }\end{array}$ & $\begin{array}{c}\text { Perkembangan } \\
\text { Built Up Area }(\%)\end{array}$ & Kota Kecil & Jumlah \\
\hline \multirow[t]{3}{*}{ Konsentris } & $\begin{array}{c}\text { Rendah } \\
(0 \%-25 \%)\end{array}$ & $\begin{array}{l}\text { Gemolong (Sragen), Jatibarang (Brebes), } \\
\text { Margoyoso (Pati), Moga (Pemalang), } \\
\text { Randudongkal (Pemalang), Sambi (Boyolali), Tayu } \\
\text { (Pati), Weru (Sukoharjo) }\end{array}$ & 8 \\
\hline & $\begin{array}{c}\text { Sedang } \\
(26 \%-50 \%)\end{array}$ & Boja (Kendal), Kayen (Pati), Wedarijaksa (Pati) & 3 \\
\hline & $\begin{array}{c}\text { Tinggi } \\
(51 \%-100 \%)\end{array}$ & Sragi (Pekalongan) & 1 \\
\hline \multirow[t]{3}{*}{ Sektoral } & $\begin{array}{l}\text { Rendah } \\
(0 \%-25 \%)\end{array}$ & $\begin{array}{l}\text { Ampelgading (Pemalang), Banyudono (Boyolali), } \\
\text { Delanggu (Klaten), Gabu (Pati), Gatak } \\
\text { (Sukoharjo), Gombong (Kebumen), Jaten } \\
\text { (Karanganyar), Klampok (Banjarnegara), Kutoarjo } \\
\text { (Purworejo), Lasem (Rembang), Margasari (Tegal), } \\
\text { Parakan (Temanggung), Pedan (Klaten), Secang } \\
\text { (Magelang), Tanjung (Brebes), Tawangmangu } \\
\text { (Karanganyar), Weleri (Kendal) }\end{array}$ & 8 \\
\hline & $\begin{array}{c}\text { Sedang } \\
(26 \%-50 \%)\end{array}$ & Wangon (Banyumas) & 1 \\
\hline & $\begin{array}{c}\text { Tinggi } \\
(51 \%-100 \%)\end{array}$ & Ampel (Boyolali), Sidareja (Cilacap) & 1 \\
\hline \multirow[t]{3}{*}{$\begin{array}{l}\text { Multiple } \\
\text { nuclei }\end{array}$} & $\begin{array}{l}\text { Rendah } \\
(0 \%-25 \%) \\
\end{array}$ & - & - \\
\hline & $\begin{array}{c}\text { Sedang } \\
(26 \%-50 \%) \\
\end{array}$ & Ajibarang (Banyumas) & 1 \\
\hline & $\begin{array}{c}\text { tinggi } \\
(51 \%-100 \%)\end{array}$ & Bawen (Semarang) & 1 \\
\hline \multicolumn{3}{|r|}{ TOTAL } & 34 \\
\hline
\end{tabular}

Untuk kota-kota kecil yang tidak berbatasan langsung atau jauh dengan kota besar perkembangan lahan terbangunnya lambat. Hal ini dikarenakan beberapa kota-kota kecil tersebut ada yang berkembang secara alami dan biasa disebut sebagai rurbanisasi. Rurbanisasi merupakan proses berubahnya masyarakat di daerah desa karena adanya surplus agraris atau perkembangan potensi lokal yang menciptakan perubahan masyarakat pedesaan seperti perdagangan dan kerajinan desa (Soetomo, 2002). Proses tersebut menciptakan ruang-ruang terbangun yang padat dengan kegiatan heterogen masyarakatnya sebagai proses terbentuknya masyarakat non pertanian. Hal ini juga dapat 
disebabkan oleh belum optimalnya sistem perkotaan yang sudah ditentukan fungsi dan perannya dalam pemerataan pembangunan di Jawa Tengah.

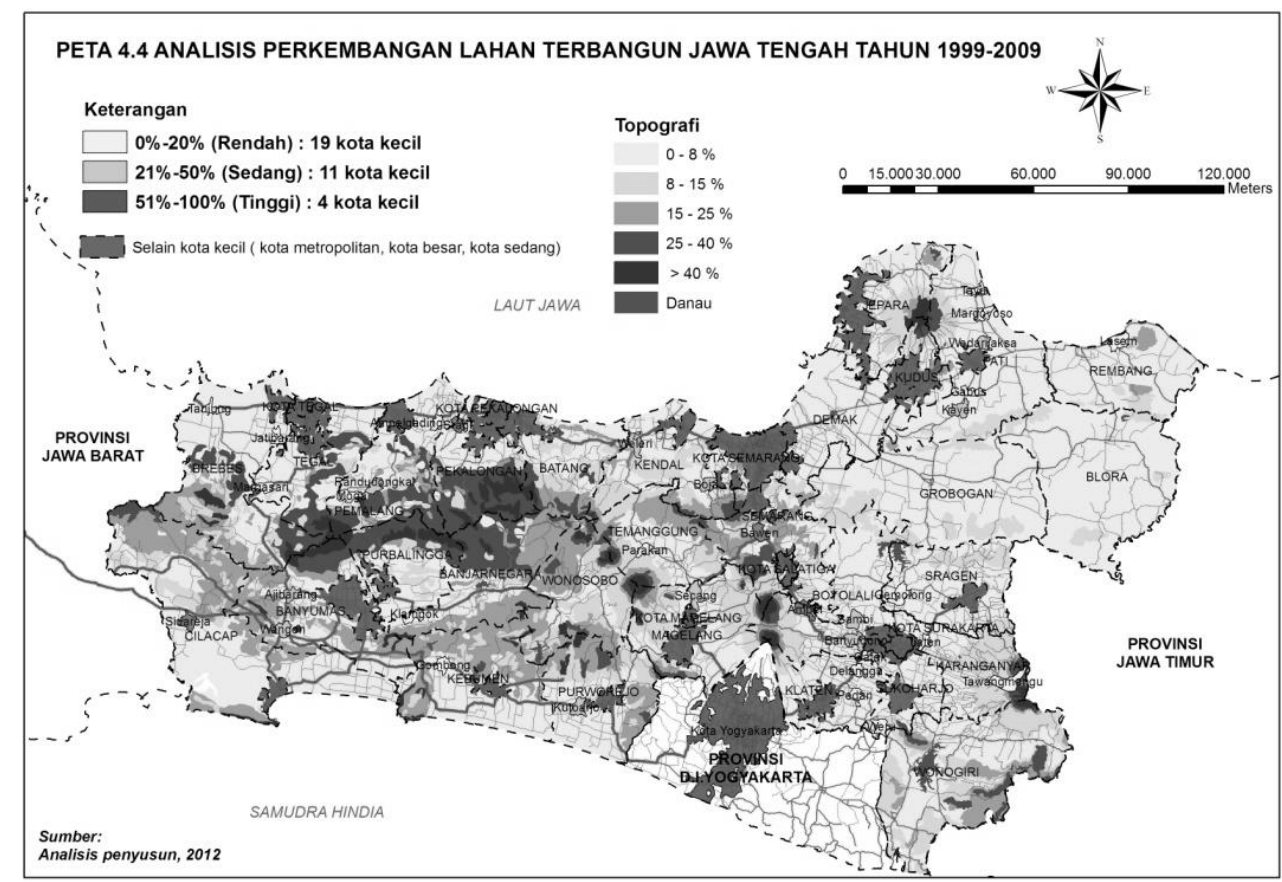

Gambar 3. Peta Analisis Lahan Terbangun Kota-Kota Kecil Jawa Tengah (25.000-50.000 jiwa)

\section{Analisis Kerapatan Jalan Kota-Kota Kecil Jawa Tengah (25.000-50.000 Jiwa)}

Berdasarkan tabel analisis sebelumya, kota-kota kecil yang terletak di dekat kota metropolitan dan kota besar memiliki tingkat kerapatan jaringan jalan tinggi dapat terjadi karena adanya faktor urbanisasi dan modernisasi. Pada analisis ini menjelaskan bahwa kota-kota kecil yang berstruktur ruang konsentris mayoritas perkembangan jaringan jalannya rendah. Hal yang sama terdapat pada kota-kota kecil yang berstruktur sektoral. Kondisi ini terbilang lambat dikarenakan hanya terdapat pusat kegiatan yang bersifat tunggal serta potensi daerah tersebut merupakan daerah rural urban yang pusat kegiatannya hanya dari sektor pertanian.

Tingkat urbanisasi yang cukup tinggi di kota besar mengakibatkan perkembangan kota menjalar ke kota-kota kecil di sekitarnya. Hal ini juga mempengaruhi tingkat kebutuhan hidup manusia seperti perumahan, perdagangan dan jasa. Meningkatnya urbanisasi dan kebutuhan hidup tersebut yang mempengaruhi perubahan fungsi lahan di kota-kota kecil tersebut. Hal ini juga berpengaruh terhadap pembangunan-pembangunan jalan baru sebagai akses untuk mempermudah manusia dalam memperoleh kebutuhan hidup karena jalan merupakan jaringan pembuka ruang untuk melakukan kegiatan. Kotakota kecil yang termasuk dalam kategori kerapatan jalan rendah mayoritas terletak jauh dengan kota besar. Faktor jarak ini merupakan salah satu faktor mempengaruhi rendahnya tingkat kerapatan jaringan jalan, Hal ini dikarenakan mayoritas kota-kota kecil tersebut tumbuh dan berkembang secara alami dan tidak ada pengaruh langsung dari kota-kota besar. 


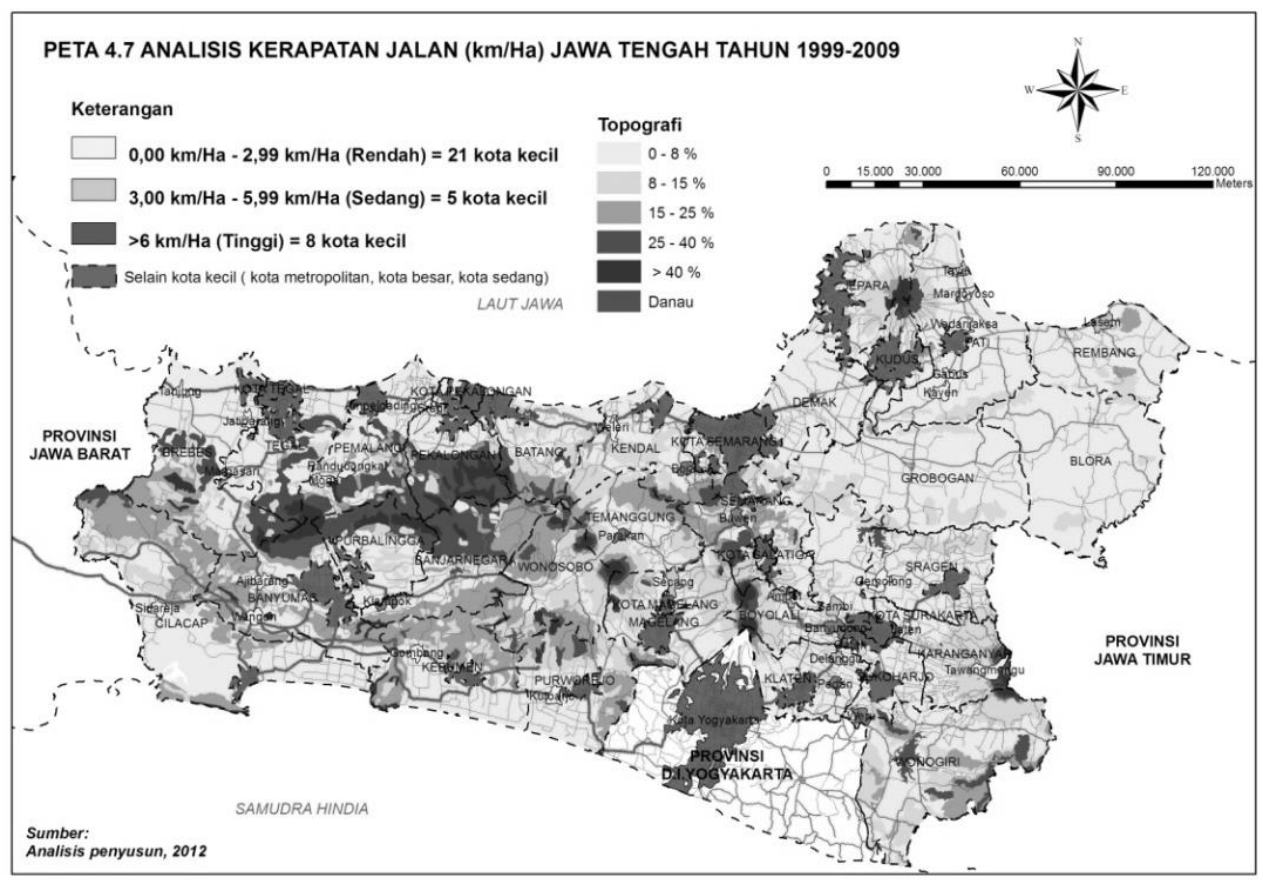

Gambar 4. Peta Analisis Kerapatan Jalan Kota-Kota Kecil Jawa Tengah (25.000-50.000 jiwa)

\section{Temuan Penelitian}

Penelitian perkembangan spasial kota kecil ini berfokus kepada aspek fisik perkotaan yaitu lahan terbangun, jaringan jalan serta struktur ruang. Analisis yang telah dilakukan antara lain analsis hirarki perkotaan, analisis perkembangan lahan terbangun, analisis kerapatan jaringan jalan dan analisis struktur ruang terhadap 34 kota kecil yang berpenduduk 25.000 sampai 50.000 jiwa. Proses analisis yang dilakukan telah memunculkan hasil-hasil yang dapat dijadikan sebagai temuan penelitian.

Sketsa generalisasi struktur ruang konsentris (1) dilihat dari tingkatan hirarkinya maka pemanfaatan ruang untuk aktivitas perdagangan dan jasa di sekitar jalan utama menempati hirarki tertinggi. Jika dilihat melalui pola perkembangannya maka dari awal wilayah studi tumbuh secara horisontal, namun khusus di sekitar jalan utama pertumbuhan kota tumbuh secara vertikal. Rute-rute transportasi dari segala penjuru memusat ke zona ini sehingga zona ini merupakan zona dengan derajat aksesibilitas tinggi. Untuk kota kecil yang berstruktur ruang konsentris mayoritas berlokasi tidak dekat dengan kota besar dan tidak pula dilewati oleh jalur arteri. Biasanya kota-kota kecil ini bersifat agraris. Perkembangan sebuah desa agraris yang maju didorong oleh jaringan aksesibilitas sehingga menciptakan kegiatan perdagangan hasil bumi dengan keluar masuknya barang kebutuhan petani yang makmur hingga menciptakan sebuah desa yang ramai dan terus berkembang menjadi kota kecil di tengah wilayah pertanian dan kota kecil tersebut perkembangannya masih sangat bergantung pada kawasan pedesaan di sekitarnya. Proses kemajuan dan berkembang pada sektor pertanian menciptakan surplus wilayah dan selanjutnya surplus wilayah tersebut menciptakan kehidupan pelayanan yang bersifat kegiatan non pertanian menjadi kehidupan perkotaan. Demikian juga dari permukimanpermukiman pedesaan yang terisolasi hidup untuk kepentingan mereka sendiri kemudian proses komunikasi berkembang dan terjadi keterhubungan antar pemukiman maka 
berkembanglah suatu pusat kegiatan yang melayani wilayah pada salah satu pemukiman tersebut.

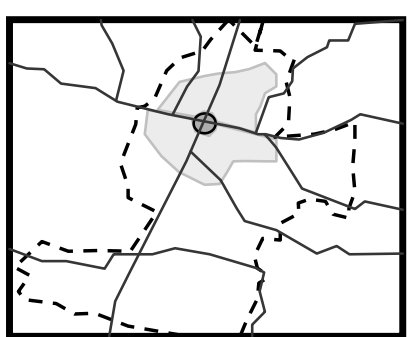

(1)

Keterangan: = pusat kota;

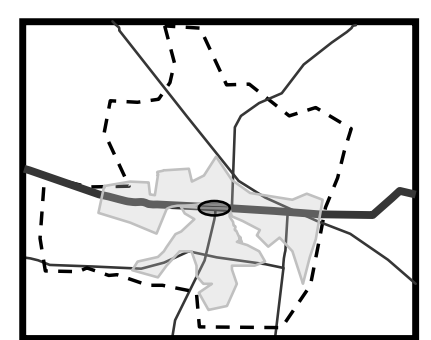

(2)

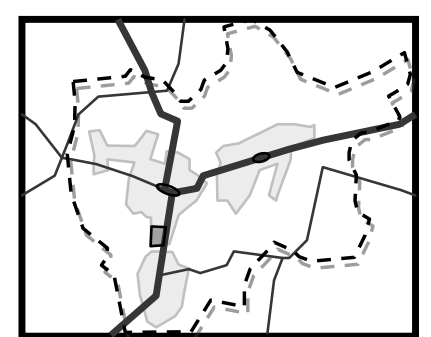

(3)
= zona pemukiman campuran
' $-\stackrel{-}{-}$ = batas wilayah; $=$ jalan

Gambar 5. Sketsa Generalisasi Struktur Ruang (1) Konsentris, (2) Sektoral, (3) Multiple Nuclei

Sketsa generalisasi struktur ruang sektoral (2) cenderung berkembang berdasarkan lingkaran-lingkaran konsentrik. Pusat kegiatan terletak di pusat kota, namun pada bagian lainnya berkembang menurut sektor-sektor yang terjadi akibat dari faktor geografi seperti bentuk lahan dan pengembangan jalan sebagai sarana komunikasi dan transportasi yang di dalamnya terdapat perbedaan kawasan kota berdasarkan jenis blok-blok berdasarkan fungsi ataupun jenis pengelompokan penduduk. Pertumbuhan secara sektoral ini dapat dipengaruhi oleh jalur transportasi maupun topografi. Untuk kasus di pansela dan pantura lebih dipengaruhi oleh adanya jalur transportasi. Hal ini dapat dilihat bahwa pusat-pusat kegiatan komersil yang merupakan kegiatan penunjang ekonomi berada di pinggir jalur transportasi. Adanya faktor aksesibiltas tersebut menyebabkan pertumbuhan ekonomi berkembang cepat. Hal ini dikarenakan lokasi tersebut merupakan lokasi strategis untuk menumbuhkan ekonomi kota.

Sketsa generalisasi struktur ruang multiple nuclei (3) mempunyai struktur yang terbentuk atas ruang-ruang, dimana penggunaan lahan yang berbeda-beda akan berkembang disekitar titik-titik pertumbuhan didalam daerah perkotaan. Jadi yang memiliki pusat bukan hanya kota, juga daerah-daerah pinggiran atau tepian kota memiliki pusat-pusat yang menaungi penduduk. Titik-titik pertumbuhan tersebut biasanya terletak pada persimpangan maupun simpul-simpul jalan baik dari jalan arteri mupun kolektor.

Berdasakan analisis yang dilakukan menjelaskan bahwa kota-kota kecil yang berstruktur ruang konsentris mayoritas mengalami perkembangan lahan terbangun yang rendah dan kerapatan jalan yang rendah. Selain itu untuk kota-kota berstruktur sektoral mayoritas juga mengalami perkembangan lahan terbangun yang dapat dibilang rendah serta kerapatan jalan yang rendah. Kota-kota kecil yang berstruktur konsentris perkembangan lahan terbangunnya terbilang lambat dikarenakan hanya terdapat pusat kegiatan yang bersifat tunggal serta potensi daerah tersebut merupakan daerah rural urban yang pusat kegiatannya hanya dari sektor pertanian. Kota kecil yang berstruktur multiple nuclei perkembangan lahan terbangunnya cukup berkembang antara tingkat sedang sampai tingkat tinggi. Hal ini dikarenakan adanya beberapa pusat kegiatan di dalam kota kecil tersebut mengakibatkan tingginya perkembangan lahan terbangun. Tabel hasil tipologi spasial yang telah dilakukan dapat dilihat pada Tabel 5.

Berdasarkan pola tipologi spasial kota-kota kecil dijelaskan bahwa kota-kota kecil di pinggiran kota besar seperti Kota Surakarta, Yogyakarta, Semarang, Tegal, Magelang, 
Salatiga dan Pekalongan perkembangan kotanya masih memiliki ketergantungan terhadap kota induk. Kota-kota kecil ini bisa disebut sebagai bagian dari sistem perkembangan dari kota induk atau disebut sebagai sub urban. Kota kecil yang berada di antara Kota Surakarta dan Kota Semarang lebih berbasis kepada perdagangan dan jasa. Hal ini dikarenakan faktor supply dan demand di kedua kota tersebut cukup tinggi seiring dengan meningkatnya urbanisasi. Peningkatan urbanisasi menimbulkan pertumbuhan ekonomi yang awalnya hanya terjadi di dalam kota, kini mulai bergerak mengarah keluar kota. Urbanisasi yang terjadi di kota-kota kecil ini adalah urbanisasi yang bersifat sosial. Pergeseran mata pencaharian yang dulunya adalah bergerak di sektor pertanian dan sekarang menjadi non pertanian. Pengaruh yang lain adalah adanya jalur transportasi yang menghubungkan kedua kota besar ini. Adanya jalur transportasi ini dapat menciptakan titik-titik pertumbuhan baru pada kota-kota kecil yang dilewati. Jalur transportasi merupakan pembuka ruang kegiatan baru. Pusat kegiatan utama pada kota-kota kecil di sekitar Kota Semarang dan Surakarta mayoritas berada di pinggiran jalur utama. Hal ini dikarenakan lokasi tersebut merupakan lokasi yang strategis untuk melakukan serta meningkatkan kegiatan ekonomi kota. Pertumbuhan ekonomi di kedua kota tersebut terbilang cepat sehingga hal ini mempengaruhi pola keruangan kota kecil tersebut.

Untuk kota-kota kecil yang terletak di jalur pantura Jawa hampir semuanya berstruktur ruang sektoral seperti di Kota Tanjung (Brebes), Ampelgading (Pemalang), Weleri (Kendal) dan Lasem (Rembang). Hal yang sama terjadi di jalur pansela Jawa seperti Kota Kutoarjo (Purworejo), Kota Gombong (Kebumen), Kota Sidareja (Cilacap) dan Kota Wangon (Banyumas). Pertumbuhan secara sektoral ini dapat dipengaruhi oleh jalur transportasi maupun topografi. Untuk kasus di pansela dan pantura lebih dipengaruhi oleh adanya jalur transportasi. Hal ini dapat dilihat bahwa pusat-pusat kegiatan komersil yang merupakan kegiatan penunjang ekonomi berada di pinggir jalur transportasi. Adanya faktor aksesibilitas tersebut menyebabkan pertumbuhan ekonomi berkembang cepat. Hal ini dikarenakan lokasi tersebut merupakan lokasi strategis untuk menumbuhkan ekonomi kota.

Hal yang sama ditemui pada kota-kota kecil yang berada di topografi dataran tinggi seperti Parakan (Temanggung) dan Tawangmangu (Karanganyar). Kedua kota tersebut berada di daerah pegunungan. Kota-kota di daerah pegunungan ini berbasis pada ekonomi pertanian. Dimana lahan pertanian masih dijadikan sebagai basis mata pencaharian. Dikatakan sektoral karena pusat kegiatan ekonomi berada di pinggir jalur utama. Biasanya terdapat pasar lokal yang menjual hasil-hasil pertanian dari daerah tersebut. Lahan terbangun yang ada hanya terdapat pada sektor-sektor tertentu dikarenakan kondisi topografi yang berbukit-bukit sehingga penduduk sekitar hanya memanfaatkan lahan yang sesuai dan layak untuk dibangun. Ada pula kota kecil yang tumbuh cepat walaupun lokasinya jauh dari jangkauan pelayanan kota besar. Hal ini dikarenakan kota tersebut berkembang secara alami dan biasa disebut sebagai rurbanisasi. Jadi, perkembangan kota tidak hanya dipengaruhi oleh urbanisasi tetapi ada faktor lain yaitu seperti comparative advantages bersifat alamiah (topografi, SDA, historis) maupun buatan (jaringan infrastruktur, fasilitas sosial).

Tabel 5. Kompilasi II Analisis Spasial Kota-Kota Kecil (25.000-50.000 jiwa) Jawa Tengah

\begin{tabular}{l|l|c|c|c|c|c|c}
\hline Nama & Kabupaten & $\begin{array}{c}\text { Luas } \\
\text { Wilayah }\end{array}$ & $\begin{array}{c}\text { Struktur } \\
\text { Ruang }\end{array}$ & $\begin{array}{c}\text { Perkembangan } \\
\text { Built Up } \\
\text { Area(\%) }\end{array}$ & $\begin{array}{c}\text { Kerapatan } \\
\text { Jalan(Km/Ha) }\end{array}$ & Tipologi & $\begin{array}{c}\text { Letak } \\
\text { Geografis }\end{array}$ \\
\hline Gemolong & Sragen & 2626,089 & konsentris & $14,0 \%$ (Rendah) & 2,63 (Rendah) & KRR & Rural Urban \\
\hline Jatibarang & Brebes & 1450,345 & konsentris & $2,0 \%$ (Rendah) & 0,69 (Rendah) & KRR & Pantura \\
\hline Margoyoso & Pati & 1395,781 & konsentris & $16,1 \%$ (Rendah) & 0,25 (Rendah) & KRR & Pantura \\
\hline Moga & Pemalang & 1817,135 & konsentris & $2,4 \%$ (Rendah) & 0,09 (Rendah) & KRR & Perbukitan
\end{tabular}


Nanda Adi Prawatya dan Jawoto Sih Setyono 29

\begin{tabular}{|c|c|c|c|c|c|c|c|}
\hline Nama & Kabupaten & $\begin{array}{c}\text { Luas } \\
\text { Wilayah }\end{array}$ & $\begin{array}{c}\text { Struktur } \\
\text { Ruang }\end{array}$ & $\begin{array}{c}\text { Perkembangan } \\
\text { Built Up } \\
\text { Area }(\%)\end{array}$ & $\begin{array}{c}\text { Kerapatan } \\
\text { Jalan }(\mathbf{K m} / \mathbf{H a})\end{array}$ & Tipologi & $\begin{array}{c}\text { Letak } \\
\text { Geografis }\end{array}$ \\
\hline Randudongkal & Pemalang & 1694,233 & konsentris & $24,7 \%$ (Rendah) & 1,87(Rendah) & KRR & Perbukitan \\
\hline Tayu & Pati & 1188,025 & konsentris & $0,6 \%$ (Rendah) & 0,39 (Rendah) & KRR & Pantura \\
\hline Sambi & Boyolali & 2263,817 & konsentris & 24,9\% (Rendah) & 5,71(Sedang) & KRS & Rural Urban \\
\hline Weru & Sukoharjo & 2169,878 & konsentris & $6,4 \%$ (Rendah) & 6,49(Tinggi) & KRT & Rural Urban \\
\hline Kayen & Pati & 2409,835 & konsentris & $36,9 \%$ (Sedang) & 2,89(Rendah) & KSR & Rural Urban \\
\hline Wedarijaksa & Pati & 1435,792 & konsentris & $31,0 \%$ (Sedang) & 1,71(Rendah) & KSR & Pantura \\
\hline Boja & Kendal & 1518,376 & konsentris & $25,6 \%$ (Sedang) & 7,40(Tinggi) & KST & Rural Urban \\
\hline Sragi & Pekalongan & 1458,334 & konsentris & $50,3 \%$ (Tinggi) & 2,96(Rendah) & KTR & Pantura \\
\hline Ajibarang & Banyumas & 1602,157 & $\begin{array}{c}\text { Multiple } \\
\text { nuclei }\end{array}$ & $26,1 \%$ (Sedang) & 0,58 (Rendah) & MNSR & Rural Urban \\
\hline Bawen & Semarang & 2004,349 & $\begin{array}{c}\text { Multiple } \\
\text { nuclei }\end{array}$ & $58,3 \%$ (Tinggi) & 6,11(Tinggi) & MNTT & Rural Urban \\
\hline Gombong & Kebumen & 1812,418 & sektoral & $8,0 \%$ (Rendah) & 1,67(Rendah) & SRR & Pansela \\
\hline Kutoarjo & Purworejo & 1946,778 & sektoral & $22,8 \%$ (Rendah) & 2,00(Rendah) & SRR & Pansela \\
\hline Margasari & Tegal & 1609,825 & sektoral & $3,7 \%$ (Rendah) & 2,52(Rendah) & SRR & Rural Urban \\
\hline Jaten & Karanganyar & 1058,513 & sektoral & 0,4\% (Rendah) & 2,78(Rendah) & SRR & Sub Urban \\
\hline Ampelgading & Pemalang & 1255,339 & sektoral & $8,5 \%$ (Rendah) & 0,02 (Rendah) & SRR & Pantura \\
\hline Gabus & Pati & 1515,62 & sektoral & $16,6 \%$ (Rendah) & 0,54(Rendah) & SRR & Rural Urban \\
\hline Tanjung & Brebes & 1613,811 & sektoral & $1,0 \%$ (Rendah) & 2,50(Rendah) & SRR & Pantura \\
\hline Tawangmangu & Karanganyar & 3649,786 & sektoral & $6,7 \%$ (Rendah) & 2,17(Rendah) & SRR & Pegunungan \\
\hline Weleri & Kendal & 2310,066 & sektoral & 21,6\% (Rendah) & 1,47(Rendah) & SRR & Pantura \\
\hline Lasem & Rembang & 2502,876 & sektoral & $18,4 \%$ (Rendah) & 5,68 (Sedang) & SRS & Pantura \\
\hline Delanggu & Klaten & 1207,132 & sektoral & $8,6 \%$ (Rendah) & 4,92(Sedang) & SRS & Rural Urban \\
\hline Secang & Magelang & 2762,677 & sektoral & $36,3 \%$ (Rendah) & 4,30 (Sedang) & SRS & Rural Urban \\
\hline Banyudono & Boyolali & 2722,348 & sektoral & $20,6 \%$ (Rendah) & 6,78(Tinggi) & SRT & Sub Urban \\
\hline Gatak & Sukoharjo & 1235,872 & sektoral & $6,4 \%$ (Rendah) & 6,98(Tinggi) & SRT & Sub Urban \\
\hline Klampok & Banjarnegara & 1783,481 & sektoral & $4,8 \%$ (Rendah) & 7,71(Tinggi) & SRT & Rural Urban \\
\hline Parakan & Temanggung & 1383,032 & sektoral & 18,4\% (Rendah) & 8,14 (Tinggi) & SRT & Pegunungan \\
\hline Pedan & Klaten & 1354,392 & sektoral & $18,3 \%$ (Rendah) & 6,82(Tinggi) & SRT & Rural Urban \\
\hline Wangon & Banyumas & 1990,294 & sektoral & $41,6 \%$ (Sedang) & 2,94(Rendah) & SSR & Pansela \\
\hline Sidareja & Cilacap & 1914,787 & sektoral & $56,9 \%$ (Tinggi) & 0,26 (Rendah) & STR & Pansela \\
\hline Ampel & Boyolali & 2597,079 & sektoral & $53,8 \%$ (Tinggi) & 3,39(Sedang) & STS & Rural Urban \\
\hline
\end{tabular}

\section{Kesimpulan Dan Rekomendasi}

\section{Kesimpulan}

Berdasarkan beberapa analisis yang telah dilakukan dan mengacu pada tujuan penelitian maka dari hasil penelitian perkembangan spasial kota-kota kecil dapat ditarik kesimpulan bahwa terdapat 3 pola perkembangan berdasarkan struktur ruang yaitu konsentris, sektoral dan multiple nuclei. Dari 3 struktur ruang tersebut dapat dilihat adanya perbedaan. Perbedaan tersebut adalah perkembangan lahan terbangun serta perkembangan jaringan jalan. Berdasakan analisis yang dilakukan menjelaskan bahwa kota-kota kecil yang berstruktur ruang konsentris mayoritas mengalami perkembangan lahan terbangun yang 


\section{Perkembangan Spasial Kota-Kota Kecil di Jawa Tengah}

rendah dan kerapatan jalan yang rendah. Selain itu untuk kota-kota berstruktur sektoral mayoritas juga mengalami perkembangan lahan terbangun yang dapat dibilang rendah serta kerapatan jalan yang rendah. Kota-kota kecil yang berstruktur konsentris perkembangan lahan terbangunnya terbilang lambat dikarenakan hanya terdapat pusat kegiatan yang bersifat tunggal serta potensi daerah tersebut merupakan daerah rural urban yang pusat kegiatannya hanya dari sektor pertanian. Kota kecil yang berstruktur multiple nuclei perkembangan lahan terbangunnya cukup berkembang antara tingkat sedang sampai tingkat tinggi. Hal ini dikarenakan adanya beberapa pusat kegiatan di dalam kota kecil tersebut mengakibatkan tingginya perkembangan lahan terbangun.

Cepat atau lambatnya perkembangan lahan terbangun di kota-kota kecil tersebut dapat dipengaruhi oleh beberapa faktor antara lain historis, urbanisasi, jarak dengan kota besar, topografi, dan aksesibilitas. Kota-kota kecil yang dilewati oleh jalan atau koridor utama sepeti koridor Semarang-Surakarta, Semarang-Yogyakarta, Surakarta-Yogyakarta, Jalur Pantai Selatan dan Utara Jawa mayoritas mengalami pertumbuhan yang cukup cepat. Kota-kota kecil yang terletak di dekat kota besar yang memiliki tingkat kerapatan jaringan jalan tinggi dapat terjadi karena adanya faktor urbanisasi dan modernisasi. Meningkatnya urbanisasi dan kebutuhan hidup tersebut yang mempengaruhi perubahan fungsi lahan di kota-kota kecil khususnya pembangunan jaringan jalan yang dalam hal ini peningkatan jaringan jalan pada suatu kota ditujukan untuk memperkuat dan memperlancar kegiatan interaksi antar daerah. Beberapa temuan studi diatas menjelaskan bahwa sifat ketergantungan kota-kota kecil di pinggiran kota besar dan di sepanjang koridor utama terhadap pusat kegiatan dari kota besar seperti Kota Semarang, Kota Surakarta, Kota Tegal, Kota Salatiga, Kota Magelang, Kota Pekalongan dan D.I.Yogyakarta ternyata masih cukup tinggi.

\section{Rekomendasi}

Berdasarkan kesimpulan diatas, maka dari itu diperlukan suatu masukan, ide maupun usulan rekomendasi untuk memperbaiki dan melanjutkan penelitian ini. Berikut merupakan rekomendasi yang dapat dipertimbangkan untuk ditindaklanjuti:

- Perlu dilakukan penelitian lanjut yang lebih bersifat mikro untuk mengetahui perkembangan spasial secara detail

- Perlu adanya penelitian tentang pengaruh struktur ruang terhadap perkembangan lahan terbangun dan jaringan infrastruktur kota kecil

- Dapat dijadikan sebagai referensi maupun acuan untuk melakukan perencanaan perkembangan kota-kota kecil di Jawa Tengah

\section{Daftar Pustaka}

Adisasmita, R. (2010). Pembangunan Kota Optimum, Efisien dan Mandiri. Yogyakarta: Graha Ilmu.

Anawati, Y. S. (2001). Kajian Feomena Urbanisme Pada Masyarakat Kota Ungaran Kabupaten Semarang. Semarang: JPWK FT UNDIP.

Bungin, M. B. (2004). Metodologi Penelitian Kuantitatif. Surabaya: Kencana Prenada Media Group.

Catanese, A. J. (1984). Pengantar Perencanaan Kota. Jakarta: Erlangga.

Creswell, J., \& Clark, V. (2007). Design and Conducting Mixed Methods Research. London: Sage Publications.

Haryono, T. J. (2010). Dampak Urbanisasi Terhadap Masyarakat Di Daerah Asal.

Jayadinata, T. (1999). Tata Guna Tanah dalam Perencanaan Perdesaan, Perkotaan dan Wilayah. Bandung: ITB. 


\section{Nanda Adi Prawatya dan Jawoto Sih Setyono 31}

Kostof, S. (1991). The City Shape Urban Pattern and Meaning Though History. Canada: Little Brown and Company.

Lynch, K. (2005). The Image of The City. Cambridge mass: MIT Press.

Nazir, M. (2003). Metode Penelitian. Jakarta: Penerbit Ghalia Indonrsia.

Nurkholis. (2008). Struktur Ruang Internal Kota Delanggu Sebagai Kota Kecil Di Koridor Solo-Jogja. Semarang: JPWK FT UNDIP

Paddison, R. (2001). Handbook of Urban Studies. SAGE Publication Ltd .

Prahasta, E. (2002). Konsep-Konsep Dasar Sistem Informasi Geografis. Jakarta: Informatika.

Prakash, M. O. (1982). Small Cities and National Development. Nagoya: United Nations Centre for Regional Development.

Prihantini. (2007). Kecenderungan Urbanisasi Pada Kota Kecil Sokaraja dan Patikraja Dalam Konteks Perkembangan Kota Purwokerto. Semarang: JPWK FT UNDIP.

Sangdji, E., \& Sopiah. (2011). Metode Penelitian : Pendekatan Praktis Dalam Penelitian. Yogyakarta: Penerbit Andi.

Soetomo, S. (2005). Dari Urbanisasi ke Morfologi Kota. Semarang: Universitas Diponegoro.

Tarigan, R. (2004). Perencanaan Pembangunan Wilayah. Jakarta: Bumi Aksara.

Yunus, H. S. (2005). Klasifikasi Kota. Yogyakarta: Pustaka Pelajar.

Yunus, H. S. (2010). Metodologi Penelitian Wilayah Kontemporer. Yogyakarta: Pustaka Pelajar. 
32 Perkembangan Spasial Kota-Kota Kecil di Jawa Tengah

JURNAL WILAYAH DAN LINGKUNGAN, 1 (1), 17-32 